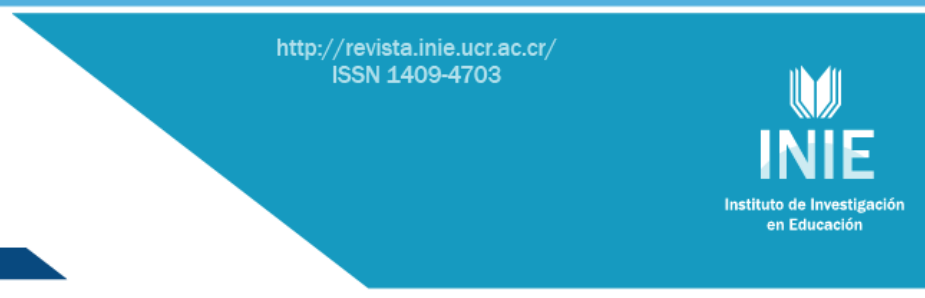

\title{
A CASE STUDY IN THE ACQUISITION OF THREE TYPES OF MORPHEMES IN ENGLISH BY A BILINGUAL CHILD
}

UN ESTUDIO DE CASO EN LA ADQUISICIÓN DE TRES TIPOS DE MORFEMAS EN INGLÉS EN UNA NIÑA BILINGÜE

\section{Volumen 16, Número 3}

Setiembre-Diciembre

pp. $1-17$

Este número se publicó el $1^{\circ}$ de Setiembre de 2016

DOI: http://dx.doi.org/10.15517/aie.v16i3.26056

Allen Quesada Pacheco

Revista indizada en REDALYC,

Revista distribuida en las bases de datos:

LATINDEX, DOAJ, E-REVIST@S, IRESIE, CLASE, DIALNET, SHERPA/ROMEO, QUALIS, MIAR

Revista registrada en los directorios:

ULRICH'S, REDIE, RINACE, OEI, MAESTROTECA, PREAL, CLACSO 


\title{
A CASE STUDY IN THE ACQUISITION OF THREE TYPES OF MORPHEMES IN ENGLISH BY A BILINGUAL CHILD \\ UN ESTUDIO DE CASO EN LA ADQUISICIÓN DE TRES TIPOS DE MORFEMAS EN INGLÉS EN UNA NIÑA BILINGÜE
}

\begin{abstract}
Allen Quesada Pacheco'
Abstract: This case study looks closely at the bilingual first language acquisition of a Costa Rican child who was raised through OPOL (One Parent One Language) and Minority Language at Home ( $\mathrm{mL} @ H$ ). The subject, Itzel, was raised in a Spanish-speaking environment and her dad is the only person that has spoken to her in English since her birth up to the present. It is explained throughout the study that the use of several native English resources complemented the acquisition of the English language. For this study, a descriptive method was used. The Wug test was applied to the subject to determine the level of acquisition of the plural morphemes, third person singular morphemes, and past tense morphemes of regular verbs. Finally a comparison of 2011 Wug test and 2014 test is made to determine mastery of these morphemes in a period of three (3) years. The results proved that the subject did acquire naturally the studied morphemes and the Wug test shows some aspects of the interlanguage development related to the acquisition of morphemes done by the subject of the study.
\end{abstract}

Key words: BILINGUALISM, LANGUAGE INSTRUCTION, LANGUAGE EDUCATION, CHILDHOOD, DESCRIPTIVE METHOD.

Resumen: Este estudio de caso centra su mirada detenidamente en la adquisición bilingüe de una lengua de una niña costarricense que aprendió dos idiomas como su primera lengua a través de los métodos OPOL -One Parent One Language- (Un Padre, Un Idioma) y Minority Language at Home ( $\mathrm{mL} @ H$ ) (La Lengua Minoritaria en el Hogar). Itzel, el sujeto de este estudio de caso, creció en un ambiente donde la lengua nativa o el idioma nativo es el español desde su nacimiento hasta su edad actual. La única persona que le habló en inglés fue su padre y para ello se complementó con recursos que desarrollaban este idioma. Se utilizó la metodología descriptiva para el estudio de casos. Además, se aplicó el examen "Wug", de Berko Gleason, para determinar el nivel de adquisición de los morfemas de los plurales de sustantivos, la tercera persona de los verbos y el pasado simple en inglés. Se hace una comparación entre los resultados del mismo examen aplicado al sujeto en el 2011 y luego en el 2014 en un período de tres (3) años, en el cual se comprobó un progreso en la adquisición de los morfemas estudiados, pues esta prueba muestra algunos aspectos del desarrollo del interlenguaje relacionado con la adquisición de morfemas.

Palabras clave: BILINGUISMO, CURSOS DE IDIOMA, LA ENSEÑANZA DE IDIOMAS, LA INFANCIA, MÉTODO DESCRIPTIVO.

\footnotetext{
${ }^{1}$ Catedrático de la Universidad de Costa Rica. Doctor of Philosophy in Curriculum and Instruction (Enseñanza del Inglés), University of Kansas (KU), E.E.U.U.
}

Dirección electrónica: allen.quesada@ucr.ac.cr

Artículo recibido: 19 de octubre, 2015

Enviado a corrección: 30 de marzo, 2016

Aprobado: 22 de aqosto, 2016 
"One language sets you in a corridor for life. Two languages open every door along the way."

-Frank Smith

\section{Introduction}

Raising a bilingual child is a challenge especially when children are brought up in a monolingual mainstream culture and country. By monolingual, it means that in Costa Rica, Spanish is the country's native language and English is taught as a foreign language rather than a second language. In other words, when most Costa Rican children learn English, they start at the elementary level, and they are in contact with the English language an hour per day in a classroom setting ( 3 hours per week in 80 percent of the country). When they leave public schools, they do not have opportunities to use the English language outside school because the context around them is full Spanish. However, it is possible to raise a bilingual child in Costa Rica (Quesada, 2011).

This is the case of Itzel who has been raised as a bilingual child. More than a challenge, it has been dedication, interest, and a long-term commitment that have made it possible. Based on the fact that children learn their first language naturally and without instruction, the one-parent one-language approach (OPOL) (Baker, 2011; Barron-Hauwaert, 2004; BarronHauwaert, 2010) was used with Itzel. Another premise that was considered in raising Itzel as a bilingual child was that if she was exposed to Spanish and English since birth this process may ensure native-like proficiency in the two languages. Wang (2008) has explained that children's brains are hard-wired for language acquisition and children up to three years old easily process both languages. That is why human capacity for language acquisition at an early age is unlimited.

In the process of Itzel's bilingual first language acquisition, her mother spoke to her in Spanish, and her father spoke to her in English. English was the minority language because Itzel used, heard and spoke English at home, but with only one of the parents, the father. The minority language, English, was enhanced through the OPOL Method (Barron-Hauwaert, 2004; Pearson \& Language, 2008). With this method, each parent speaks only the language that is native to that parent when communicating with the child. Children quickly learn to associate a particular language with the appropriate parent (Quesada, 2011).

This paper analyzes Itzel's English production of three different morphemes: plurals (s, $\mathrm{z}, \mathrm{iz}$ ), past tense endings $(/ \mathrm{t} / \mathrm{/} / \mathrm{d} /$, /id/, and use of the third person singular (s, $\mathrm{z}, \mathrm{iz}$ ). A comparative study using the Wug test (Berko, 1958) was done during two stages of her life, when she was four years old and when she turned seven. The paper provides an overview of 
Itzel's major turning points in her short life history. It also gives an explanation of the Wug test and its implication; and finally, a comparative analysis of Itzel's morphemes is displayed.

\section{Itzel's major turning points in her life history}

\subsection{Birth - three years}

Since birth, Itzel was exposed to both English and Spanish languages. Itzel's mother has talked to her in Spanish; on the other hand, her father has talked to Itzel in English. The major turning points in this section will be about Itzel's contact with the English language which was the minority language in this case study. Indeed Itzel has been exposed to Spanish more than to English because all of Itzel's relatives spoke to her in Spanish during the baby talk stage. There was a big chance that the majority language (Spanish) could become the dominant language. The main challenge was making the minority language (English) a priority from the get-go in order to strengthen and counterbalance the weight of exposure from both parents.

Since Itzel's dad was interested in raising a simultaneous bilingual child, he decided to use the OPOL (One-Parent-One-Language) approach thoroughly to accomplish this goal. Baker (2011) has explained that One-Parent-One-Language (OPOL) approach has been the suggested strategy for raising a bilingual child, mainly because it seems to be a very simple method to implement for the parents: one parent speaks one language to a child and the other parent speaks in the other language.

In order to be effective and provide sufficient input to the child, Itzel's father used many more "language supplements", like songs, games, native speakers, and so forth, so that Itzel could experience the English language in a variety of ways. Nonetheless, language supplements were not enough in this process; the major requirement for the OPOL approach to work and provide long-term results was the dad's consistency and persistence as well as patience and commitment when socializing with her. These elements were paramount in Itzel's bilingual first language acquisition (BFLA).

As mentioned above, Itzel's exposure to the English language depended on quality and quantity. Since her birth to the age of two or three, talking, socializing and more talking to Itzel in English produced a tremendous impact on her language development. Added to this, in order to nurture the acquisition of English most of the time was dedicated to exposing Itzel to higher percentages of the target language like playing and singing English songs, reading aloud stories, playing games in English (word games, card games, storytelling games, board 
games, among others. Her performance in the English language was pretty much native-like in term of pronunciation and vocabulary use with some interlanguage use which is normal at this stage.

\subsection{Four years old - Immersion opportunity in Utah}

When Itzel was turning four, her parents had the opportunity to live in Utah for four months. It was amazing that the very first day in Utah, early in the morning, Itzel was taken to a playground, and she started interacting with other children and their mothers as if she had lived there for years. Itzel did not show signs of fear or communication problems at all as she communicated with American children naturally. Actually her vocabulary was more sophisticated than the native speaking children her age due to the fact that she had been exposed to grown-up words and expressions. That day she said for example "the day is overcast", meaning "the day is covered with clouds".

In a day to day basis, while Itzel lived in Utah, she just stayed with her mother at home. However, she would watch children's TV programs as she did in her home country. Every morning, her dad would go to school to do his research project, and when he arrived home, he would take advantage of the environment and people around to immerse Itzel in the English-speaking community in order to enhance her acquisition of the English language. This was done at the playground most of the time, when she interacted with other children of the same age; at different locations with her father's colleagues at the university; at church on Sundays, and mostly at home because winter was harsh and Itzel had to spend hours during the day in the apartment. On Fridays her mother would take her to a library for 30-minute storytelling sessions which she enjoyed a lot. At the same time, Itzel had the opportunity to interact with students and teachers at the university and with a host family. It is important to state that the OPOL method was continued in Utah.

\subsection{Return to Costa Rica}

After four months of immersion, Itzel returned to Costa Rica, and continued with OPOL at home. Since Itzel was growing, her dad looked for other resources that could help generate listening and speaking skills in Itzel's English language development. In his search for an online learning platform for children, the website abcmouse.com@ served its purpose. ABCmouse is a site for children ages 2 to 6. The Step-by-Step Learning Path presents the full $\mathrm{ABCmouse.com} \mathrm{curriculum} \mathrm{in} \mathrm{a} \mathrm{carefully} \mathrm{designed} \mathrm{program} \mathrm{of} \mathrm{more} \mathrm{than} 450$ lessons in six 
levels. As a child completes each lesson, he or she is guided to the next one and is motivated to continue learning by tickets and rewards system. This platform really helped Itzel in her literacy development and oral communication skills. Aside from this platform, a mobile device (Ipad) has been very useful for the development of listening skills in her acquisition of English as a bilingual first language child. Itzel has had the opportunity to listen to stories in different applications such as Sweet Dream Lullabies (Children's story book), Snow White and the Seven Dwarfs, Play Tales, LeapFrog Songs, Kids Educational Counting Games, among many others.

\subsection{School year}

At the age of five, Itzel started attending pre-school. At home, her dad always continued using the OPOL approach. By this age, Itzel was a fluent speaker of the English language and any native speaker would consider her a native-like. She made the same mistakes when speaking as any native speaking children of her age. At school, she even spoke better than her English teachers. Her pronunciation was excellent, too. From the age of five on, Itzel started developing her reading and writing skills. Itzel's parent developed a belief that when Itzel started to read and write, she might confuse the two languages: English and Spanish. However, her interlanguage development facilitated both reading and writing in English and in Spanish. Her dad was always persistent and consistent in his dedication to the minority language, English.

\section{Children's Literacy Development}

Itzel's language development is supported by studies of different scholars who have designed a model for children's literacy development (Dunst, Trivette, Masiello, Roper \& Robyak, 2006). According to these scholars, children's literacy development is divided into three areas: early communication, language development and literacy development on infants, toddlers and preschoolers (from birth to five or six years old). This development includes three stages: pre literacy, emergent literacy, and early literacy (Lonigan, 2006; Van Kleeck, 1998).

The first stage, pre literacy development, covers from birth to approximately 12-15 months of age. During this period, any children (bilingual or monolingual) undergo through a number of important communication and literacy-related skills, including, but not limited to, joint attention, nonverbal (gestural) communication, vocalizations (cooing and babbling), 
speech and language perception, and phoneme speech stem acquisition (Armbruster, Lehr, \& Osborn, 2003a; Parlakian, 2003). Many of the activities children are involved in include the following: looking and recognizing, picture recognition and comprehension, book handling and play, and child behavior during story reading as some of the pre literacy behavior that infants master on their way to becoming literate. The kinds of activities that are the contexts for pre literacy development include, but are not limited to, parent/child lap games, singing to infants, word play, and touching and talking (Armbruster, Lehr, \& Osborn, 2003b; Parlakian, 2003).

The second stage, early literacy development, encompasses the toddler period of development from 12-15 to approximately 30 months of age. This period includes the following:

...the acquisition of first words, the production of conventional speech acts (requesting, attention getting, describing, etc.), vocabulary development, language use, language comprehension, symbol and print recognition, and the development and emergent understanding of the association between print and the meaning of text essential for subsequent reading, writing, and other literacy-related skills. (Whitehurst \& Lonigan, 2001, p. 3)

Finally, early literacy development, from 30 months to 5 years old, includes the mastery of conventional literacy skills, such as understanding word units and phonemes, metalanguage capabilities (analyzing language, "playing" with language, etc.), invented spelling, echo reading, and letter and word recognition, among others (Ferreiro \& Teberosky, 1998; Fitts, 2005; Shanahan \& Shanahan, 2008).

The following section deals with the Wug Test. This section briefly explains what the Wug test is, what it is used for and how it values the acquisition of morphemes.

\section{The Wug Test}

In a study conducted by Brown (1973) about the order of acquisition of fourteen (14) morphemes in English, he concluded that the order of acquisition of morphemes is similar despite the different family backgrounds and regardless of the rate of exposure in the following order: present progressive, prepositions, plurals, irregular past forms, possessives, articles, regular past forms, third person singular, auxiliary be. (Mitchell, Myles \& Marsden, 2013). 
In an attempt to trace Itzel's level of acquisition of some of these morphemes, a Berko study was developed, through the Wug Test. Jean Berko Gleason is a psycholinguist who has made outstanding contributions to the understanding of language acquisition in children. She is the mother of the "Wug test" whose findings opened up new perspectives for the world of linguistics when it was published in 1958. The test demonstrated that children as young as three or four can internalize complex grammatical codes that no one has necessarily ever tried to teach them - like forming plurals - and apply these rules broadly, even to made-up words called "wugs," that is, words that they have never heard before (Rosenbaum, 2014a).

As Berko (as cited in Rosenbaum, 2014b) has explained the wug study proved that "children are not simply learning bits and pieces of the adult linguistic system but are constructing generative systems of their own and that this results not from adult instruction but from the children's inborn grammatical capacity." Murphy (2011) conducted an interview with Jean Berko and sought to know whether the Wug's work interpretations have changed throughout the past six decades. Berko's conclusions were that "young children do have rules; they know more than memorize individual words and this is shown by the fact that they can inflect words that they have never heard before, and thus cannot have memorized" (p. 1). Berko (as cited in Murphy, 2011) added in this interview that the Wug test somehow "proved Chomsky's theory that children have an innate language acquisition device" (p. 2). The innateness hypothesis is supported by the following example provided by Golato (2005):

...when child acquirers of English were shown a picture of a fictitious animal and told that it was a wug, they were able to produce its correct plural form: wugs. Since the children in these studies had never heard the word wug before (and presumably had never heard its plural form either), the results were taken as evidence that children are able to use a suffixation rule in order to create regular English plural and past tense forms (p. 1)

This example tries to prove that children are born with a language acquisition device (LAD) mentioned in the previous paragraph. In addition, Berko's Wug test challenges to examine the child's use of morphological rules of different types, under varying phonological conditions for native speakers. To do this, a series of nonsense words are invented or made up, following the rules for possible sound combinations in English. Picture-like colorful cartoons are depicted that show animals, objects, and people in action (Berko, 1958). The following hand-drawn images are examples of the original Wug test: 

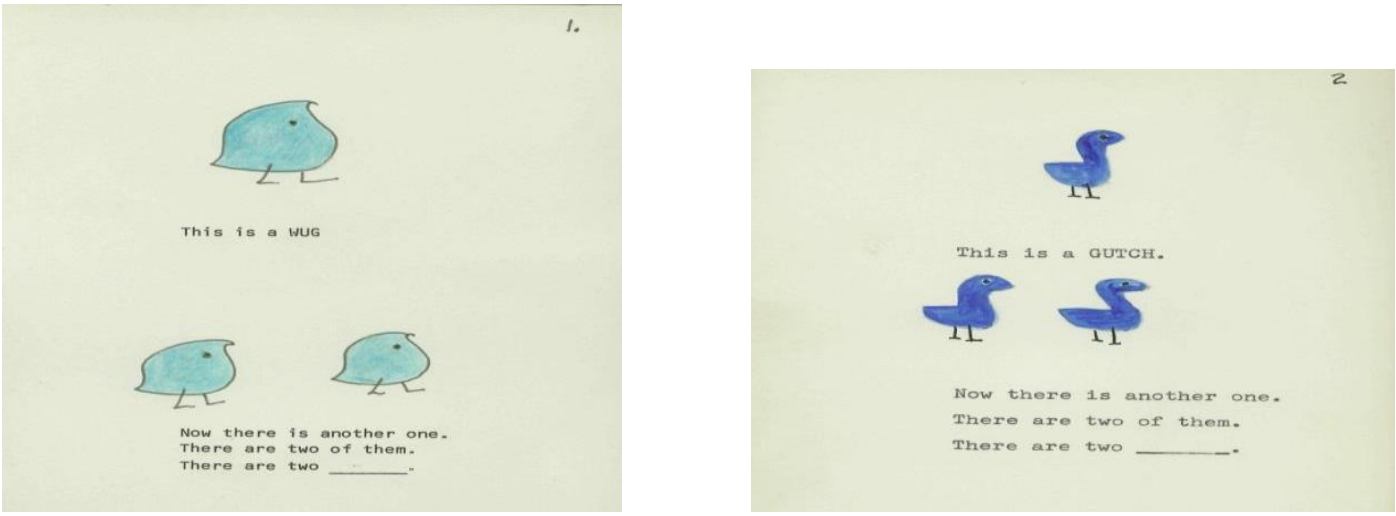

1. The Wug and Wug Test $\odot$ Jean Berko Gleason 2006. 2. The Wug and Wug Test $\odot$ Jean Berko Gleason
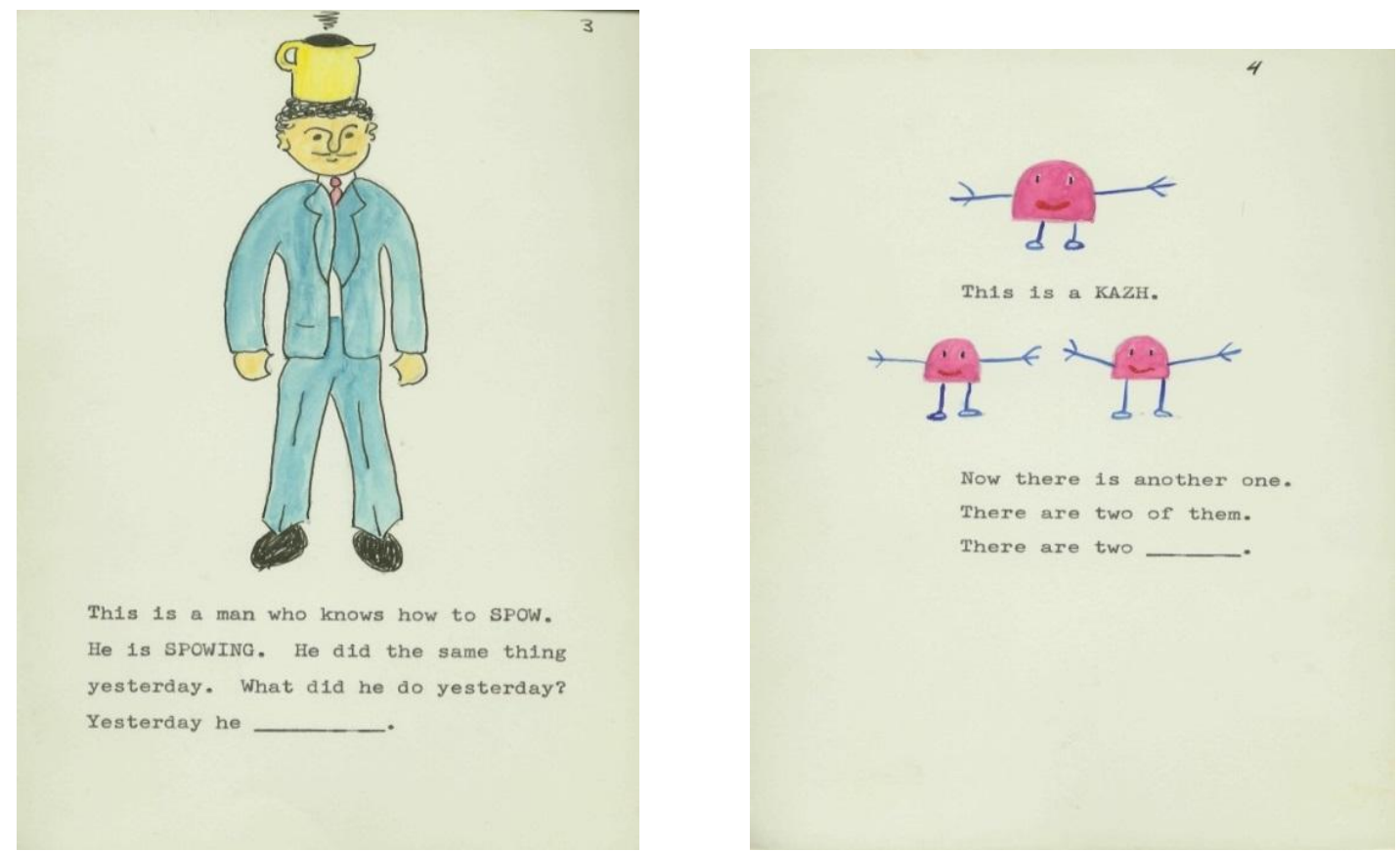

3. The Wug and Wug Test @ Jean Berko Gleason 2006. 4. The Wug and Wug Test $\odot$ Jean Berko Gleason

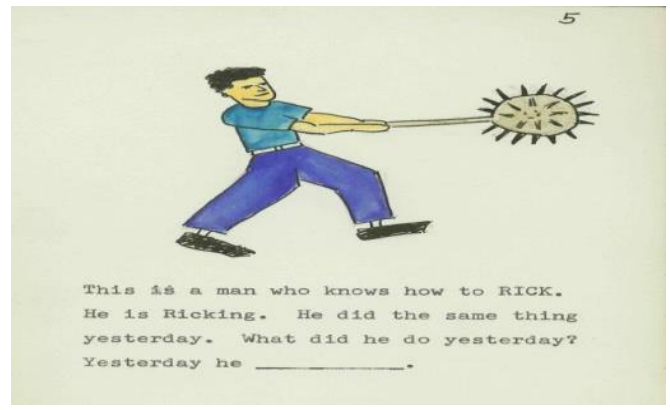

5. The Wug and Wug Test $\odot$ Jean Berko Gleason 2006. .

Commercial use prohibited. 
Each one of the images in the Wug test has a purpose or objective:

1. Image one detects the level of acquisition of the pronunciation of the plural form of nouns that end in a voiced sound. This plural form is pronounced /z/. The word "wug" (which is a hypothetical word) ends in a voiced sound. When you add an "s" for the plural form, this "s" ending is pronounced /z/, as in rugs, cars, dogs, beds, rooms, etc.

2. Image two detects the level of acquisition of the pronunciation of the plural form of nouns that end in "ch", " $x$ ", "sh", "ss" "zh", etc.; in these cases, the plural form is pronounced /iz/. The word "gutch" end in "ch". When you have the plural form "gutches", this "es" ending is pronounced "iz".

3. Image three detects the level of acquisition of the pronunciation of the "ed" ending of the past tense of irregular verbs. The hypothetical verb used in this test is "spow". A comparison is made between the present progressive of this verb (the boy is spowing) and the simple past tense. This verb ends in a voiced sound (vowel sound) and its pronunciation should be $/ \mathrm{d} /$.

4. Image four follows the rule for the pronunciation of nouns that end in "ch", "x", "sh", "ss" "zh". When they are pluralized, these endings are pronounced /IZ/.

5. Image five detects the level of acquisition of the pronunciation of the "ed" ending of the past tense of regular verbs. The hypothetical verb used in this test is "rick" that does not visually portray the real meaning of this verb. A comparison is made between the present progressive of this verb (the boy is ricking) and the simple past tense. This verb ends in a voiceless sound $(k)$ and its pronunciation should be /t/ or /rikt/.

Aside from these examples, Berko's Wug test determines the level of acquisition of the use of nouns or verbs that act as adjectives, like the example below (quirks vs quirked dog). In this case, the "ed" of quirk is pronounced /t/ because the noun ends in a voiceless sound.

This ls a doe with guIfuks on him. He Is all covered with guIfKS. What kind of dob 1 s he? He $1=0$ a doe. 
Based on the objectives of the Wug Test, the following section pretends to give an overview of the theoretical foundation of the different morphemes for this study: pronunciation of the plural forms of nouns, third person singular verb endings, and past tense of regular verbs.

\section{Pronunciation of Morphemes}

The pronunciation of the plural of nouns, the past tense ending of regular verbs, the possessive forms, and the third person singular of the simple present tense can be explained in the table 1:

Table 1. Pronunciation of the -ed ending and Pronunciation of plurals and third person singular

-ed Pronunciation -s Pronunciation

$/ \mathrm{ld} / / \mathrm{t} / / \mathrm{d} / / \mathrm{iz} / / \mathrm{s} / / \mathrm{Z} /$

wanted helped called races sleeps crabs

needed looked cleaned buses books words

washed offered boxes hats fans

kissed loved kisses myths plays

\section{VOICED VOICELESS VOICED SIBILANT VOICELESS}

Crumpler (n.d.) has summarized the pronunciation of the -ed ending of the past tense of regular verbs and has explained some teaching guidelines through charts for instructional purposes with English Language Learners (ELLs) as follows in the scheme 1:

\section{Scheme 1}

\begin{tabular}{|c|c|c|c|c|c|c|c|c|c|c|c|c|}
\hline $\begin{array}{c}\text { Linguistic } \\
\text { Symbol }\end{array}$ & \multicolumn{2}{|c|}{ p } & \multicolumn{2}{|c|}{ k } & \multicolumn{2}{|c|}{$f$} & \multicolumn{2}{|r|}{ s } & \multicolumn{2}{|c|}{ sh } & \multicolumn{2}{|r|}{ ch } \\
\hline $\begin{array}{l}\text { Example \& } \\
\text { practice }\end{array}$ & $\begin{array}{l}\text { With v } \\
\text { not mo } \\
\text { hand } \\
\text { thro } \\
\text { vocal } \\
\mathrm{m}\end{array}$ & $\begin{array}{l}\text { chords } \\
\text { g, place } \\
\text { tly over } \\
\text { o feel } \\
\text { rds not } \\
\text { ng }\end{array}$ & $\begin{array}{r}\text { With vc } \\
\text { not mo } \\
\text { hand } 8 \\
\text { thro } \\
\text { vocal } \\
m\end{array}$ & $\begin{array}{l}\text { al chords } \\
\text { ng, place } \\
\text { tly over } \\
\text { to feel } \\
\text { ords not } \\
\text { ving }\end{array}$ & $\begin{array}{l}\text { With v } \\
\text { not mo } \\
\text { hand } 8 \\
\text { thro } \\
\text { vocal } \\
m\end{array}$ & $\begin{array}{l}\text { al chords } \\
\text { ing, place } \\
\text { ntly over } \\
\text { to feel } \\
\text { ords not } \\
\text { ving }\end{array}$ & $\begin{array}{r}\text { W } \\
\text { ch } \\
\text { mov } \\
\text { hand } \\
\text { thro } \\
\text { vocal }\end{array}$ & $\begin{array}{l}\text { vocal } \\
\text { ds not } \\
\text { g. place } \\
\text { ntly over } \\
\text { to feel } \\
\text { hords not } \\
\text { ving }\end{array}$ & $\begin{array}{r}\text { Wi } \\
\text { ch } \\
\text { mov } \\
\text { hand } \\
\text { thro } \\
\text { vocal } \\
n\end{array}$ & $\begin{array}{l}\text { vocal } \\
\text { ds not } \\
\text { g. place } \\
\text { ntly over } \\
\text { to feel } \\
\text { hords not } \\
\text { ving }\end{array}$ & $\begin{array}{l}\text { With ve } \\
\text { not mo } \\
\text { hand } 8 \\
\text { throat } \\
\text { chords }\end{array}$ & $\begin{array}{l}\text { cal chords } \\
\text { ving, place } \\
\text { ently over } \\
\text { feel vocal } \\
\text { not moving }\end{array}$ \\
\hline $\begin{array}{l}\text { Words for } \\
\text { sound } \\
\text { practice }\end{array}$ & $\begin{array}{l}\text { help } \\
\text { tip }\end{array}$ & $\begin{array}{l}\text { helped } \\
\text { tipped }\end{array}$ & $\begin{array}{l}\text { look } \\
\text { cook }\end{array}$ & $\begin{array}{l}\text { looked } \\
\text { cooked }\end{array}$ & $\begin{array}{l}\text { stuff } \\
\text { laugh }\end{array}$ & $\begin{array}{l}\text { stuffed } \\
\text { laughed }\end{array}$ & $\begin{array}{c}\text { miss } \\
\text { dice } \\
\text { fix }\end{array}$ & $\begin{array}{l}\text { missed } \\
\text { diced } \\
\text { fixed }\end{array}$ & $\begin{array}{l}\text { fish } \\
\text { trash }\end{array}$ & $\begin{array}{l}\text { fished } \\
\text { trashed }\end{array}$ & $\begin{array}{l}\text { march } \\
\text { match }\end{array}$ & $\begin{array}{l}\text { marched } \\
\text { matched }\end{array}$ \\
\hline
\end{tabular}

Source: Crumpler (n.d., parr. 8) 
Some of the guidelines provided by Crumpler (n.d.) have clarified that voiceless consonants happen when the vocal cords do not vibrate. Students are directed to touch their vocal chords and feel the voiceless sounds when the regular verbs are in their simple form (help, look, miss, etc.); students are asked to compare other sounds of regular verbs that have vibration or voiced sound to mark the difference. These explanations are important because they help students become aware of the voiceless sounds so that when the -ed ending is placed, this ending is pronounced as /t/ (see Scheme 2).

\section{Scheme 2}

\begin{tabular}{|c|c|c|c|c|c|c|c|c|c|c|c|c|}
\hline $\begin{array}{c}\text { Linguistic } \\
\text { Symbol }\end{array}$ & & b & & $\mathrm{g}$ & \multicolumn{2}{|c|}{ th } & \multicolumn{2}{|c|}{$\mathbf{v}$} & \multicolumn{2}{|c|}{$z$} & \multicolumn{2}{|c|}{ 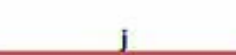 } \\
\hline $\begin{array}{c}\text { Example } 8 \\
\text { practice }\end{array}$ & $\begin{array}{r}\text { With } \\
\text { mo } \\
\text { hanc } \\
\text { thr } \\
\text { vo }\end{array}$ & $\begin{array}{l}\text { cal chords } \\
\text { g. place } \\
\text { ently over } \\
\text { t to feel } \\
\text { i chords } \\
\text { oving }\end{array}$ & $\begin{array}{l}\text { With } \\
\text { mo } \\
\text { hanc } \\
\text { thr } \\
\text { vo }\end{array}$ & $\begin{array}{l}\text { cal chords } \\
\text { g. place } \\
\text { ently over } \\
\text { t to feel } \\
\text { chords } \\
\text { oving }\end{array}$ & $\begin{array}{r}\text { With vo } \\
\text { moving. } \\
\text { gently o } \\
\text { feel vo } \\
\mathrm{m}\end{array}$ & $\begin{array}{l}\text { al chords } \\
\text { lace hand } \\
\text { r throat to } \\
\text { l chords } \\
\text { ring }\end{array}$ & $\begin{array}{r}\text { Wi } \\
\text { choro } \\
\text { pla } \\
\text { gen } \\
\text { thro } \\
\text { voce } \\
m\end{array}$ & $\begin{array}{l}\text { vocal } \\
\text { moving. } \\
\text { hand } \\
\text { y over } \\
\text { to feel } \\
\text { chords } \\
\text { ving }\end{array}$ & $\begin{array}{l}\text { With vo } \\
\text { movi } \\
\text { hand } \\
\text { thro } \\
\text { voca } \\
m\end{array}$ & $\begin{array}{l}\text { al chords } \\
\text {, place } \\
\text { ntly over } \\
\text { to feel } \\
\text { chords } \\
\text { ving }\end{array}$ & $\begin{array}{l}\text { With vo } \\
\text { moving, } \\
\text { gently } \\
\text { to feel } \\
m\end{array}$ & $\begin{array}{l}\text { al chords } \\
\text { lace hand } \\
\text { ver throat } \\
\text { cal chords } \\
\text { ving }\end{array}$ \\
\hline $\begin{array}{l}\text { Words for } \\
\text { sound } \\
\text { practice }\end{array}$ & $\begin{array}{l}\text { grab } \\
\text { blab }\end{array}$ & $\begin{array}{l}\text { grabbed } \\
\text { blabbed }\end{array}$ & $\begin{array}{l}\text { hug } \\
\text { mug }\end{array}$ & $\begin{array}{l}\text { hugged } \\
\text { mugged }\end{array}$ & $\begin{array}{l}\text { breathe } \\
\text { teethe }\end{array}$ & $\begin{array}{l}\text { breathed } \\
\text { teethed }\end{array}$ & $\begin{array}{l}\text { save } \\
\text { wave }\end{array}$ & $\begin{array}{l}\text { saved } \\
\text { waved }\end{array}$ & $\begin{array}{l}\text { please } \\
\text { ooze }\end{array}$ & $\begin{array}{l}\text { pleased } \\
\text { oozed }\end{array}$ & $\begin{array}{l}\text { manage } \\
\text { salvage }\end{array}$ & $\begin{array}{l}\text { managed } \\
\text { salvaged }\end{array}$ \\
\hline
\end{tabular}

Source: Crumpler (n.d., parr. 11)

Likewise, similar practices are provided for voiced consonants as the ones in the previous chart that indicates that voiced consonants happen when the vocal chords vibrate. English Language Learners (ELLs) touch their vocal chords and feel the vibration of the verbs in their simple forms so that they can understand what voiceless and voiced consonants are (Avery \& Ehrlich, 1992; Bowen \& Marks, 1992). This is done to help students understand that when the verb ends in a voiced consonant and that when the -ed is placed, this ending is pronounced $/ \mathrm{d} /$.

Added to this, Crumpler (n.d.) has simplified the pronunciation of the -ed past tense of regular verbs that end in /t/ and / $\mathrm{d} /$ in their simple form (rest, test, attend, fold, add, etc). When the past tense is added to these verbs, the pronunciation is /ld/ (see Scheme 3).

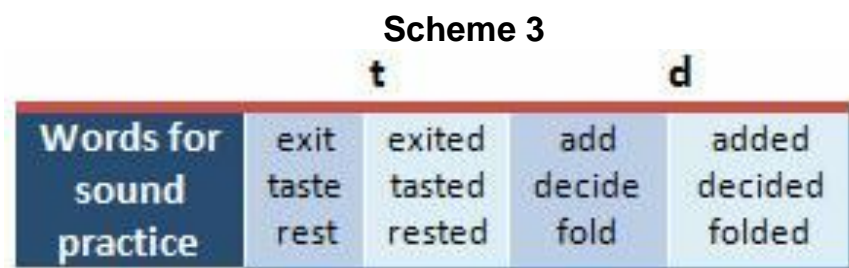

Source: Crumpler (n.d., parr. 6) 
The following section deals with the methodology procedure used in the study. The Wug test was applied in two different occasions to the subject and a spontaneous conversation was given to check on the subject's natural acquisition of some of the morphemes studied.

\section{Methodological Procedure}

\subsection{Type of Research}

This research is a descriptive case study since it describes an intervention or phenomenon and the real-life context in which it occurred (Yin, 2003). Data was collected through the Wug test to determine the subject's interlanguage level of acquisition of three morphemes in English, that is, the third person singular of verbs, the plural forms of nouns, and the past tense of regular verbs). Besides, a recorded spontaneous conversation with the subject was used to see her natural application of the morphemes in an informal speech. During the Wug test application, the subject was shown a set of pictures with nonsense words. That is, the child was shown simple pictures of an imaginary creature or activity, with a nonsense name, and prompted to complete a statement about it as follows:

2. "This is a WUG. Now there is another one. There are two of them. There are two .. Or

3. This is a dog with QUIRKS on him. He is all covered in QUIRKS. What kind of a dog is he? He is a dog.

4. This is a man who knows how to SPOW. He is SPOWING. He did the same thing yesterday. What did he do yesterday? Yesterday he

A child who knows that the plural of witch is witches may have heard and memorized that pair, but a child responding that the plural of wug (which he presumably has never heard) is wugs, has apparently inferred (perhaps unconsciously) the basic rule for forming plurals.

\subsection{Subject}

This is a single subject case study. The subject's name is Itzel. She is seven years old and she has been raised as a bilingual first language child. She was exposed to the OPOL approach since birth. 


\subsection{Instrument}

The instrument used to determine the subject's level of acquisition of English phonemes was a Wug Test. The test was applied when the subject was 4 years old, and reapplied when she was 7 years old. Also, a recorded speech of the subject was used to get the use of the morphemes in a natural setting.

\section{Results}

The results are summarized in tables for a clearer understanding of the pronunciation of the morphemes for plurals and for the past tense of verbs both when the subject was 4 and 7 years old.

Table 2

Results of the Wug test when subject was 7 years old

\begin{tabular}{lcc}
\hline & $\begin{array}{c}\text { Wug Words Test Results Subject's Pronunciation } \\
\text { of morphemes }\end{array}$ & Comments \\
\hline Wugs & $\mid \mathrm{z} /$ & \\
\hline Gutches & /iz/ & The subject didn't pronounce $/ \mathrm{t} / \mathrm{iz}$ \\
Kazhes & $/ \ldots /$ & Correct use of diminutives \\
$\begin{array}{l}\text { To rick } \\
\text { was ricking }\end{array}$ Wuggy & /z/ & The subject didn't pronounce \\
Tors & "../ & \\
a quirk dog & $\mid \mathrm{z} /$ & \\
Luns & /iz/ & \\
Nizzes & &
\end{tabular}

Table 2 portrays the pronunciation of the plural forms of nonsense words from the Wug test. Clearly, the subject has acquired the /s/, /z/, and /Iz/ pronunciation of the plurals. The test included the nonsense word "quirk" which expected the subject to use it as an adjective "quirked dog" (a dog with spots). The subject did not pronounce the /t/ in "quirked".

Table 3 compares the application of the Wug Test in 2011 and 2014. A first study was performed in BYU (Brigham Young University) in Utah. Since this study was performed when the subject was four years old, a comparison has been made on the results obtained in that year and in the year 2014 when this current study was made. In 2014, the subject was seven years old. 
Table 3

Comparative results of the pronunciation of the morphemes in 2011 and 2014

\begin{tabular}{lll} 
Morphemes & Occurrences & Results \\
\hline & 2011
\end{tabular}

2011

Occurrences

\begin{tabular}{cccc}
\hline$/ \mathrm{s} /$ & 2 & $100 \%$ deleted $^{*}$ & $100 \%$ correct 2 \\
\hline$/ \mathrm{z}$ & 8 & $75 \%$ pronounced $/ \mathrm{s} /$ & $100 \%$ correct 8 \\
$/$ & & $25 \%$ deleted & \\
\hline liz/ & 4 & $75 \%$ deleted & $100 \%$ correct 4 \\
& & $25 \%$ pronounced $/ \mathrm{s} /$ &
\end{tabular}

\begin{tabular}{cccc}
\hline$/ \mathrm{t} /$ & 3 & $100 \%$ correct & $75 \%$ correct 4 \\
\hline$/ \mathrm{d} /$ & 1 & $\begin{array}{c}100 \% \text { deleted } \\
\text { (use of the base form) }\end{array}$ & $100 \%$ correct 7 \\
\hline /id/ & 1 & $\begin{array}{c}100 \% \text { deleted } \\
\text { (use of the base form) }\end{array}$ & $75 \%$ correct 4 \\
\hline
\end{tabular}

*deleted is the term used by the previous researcher-- deleted is used as omitted

The results portrayed in table 3 have demonstrated the progress of Itzel's use of the morphemes after three years. In 2011 Itzel was immersed in an English-speaking environment in Utah. Her use of the morphemes ranged from 0 to $25 \%$. In the test performed by Itzel in the year 2014 revealed that the use of the morphemes ranged from $75 \%$ to $100 \%$; the only two morphemes that were pronounced $75 \%$ correct in four occurrences or instances were the morphemes /t/ and /ld/. The child did not substitute the morpheme, that is, she simply did not pronounce it.

It is important to highlight that during the Wug Test, there was some verbal interaction that was recorded between the researcher and the subject, not related to the Wug Test. The following analysis determines that the subject has indeed acquired the morphemes which are the focus of this study since the researcher elicited the pronunciation of other verbs or nouns in a naturalistic setting that are not nonsense verbs or nouns; on the contrary, they are verbs or nouns used in the subject's natural environment or daily life. The purpose of including this information in this study is to provide rich data of Itzel's bilingual first language acquisition (BFLA) for future arguments. The following table describes her natural use of the morphemes which are studied in this paper: 
Table 4

Other words and verb endings pronounced by the subject in a recorded spontaneous conversation

\begin{tabular}{|c|c|c|}
\hline $\begin{array}{c}\text { Regular and Irregular } \\
\text { Verbs in the Past } \\
\text { tense }\end{array}$ & $\begin{array}{l}\text { Third person } \\
\text { singular }\end{array}$ & Plurals \\
\hline Saw & walks /s/ & bridges /iz/ \\
\hline watched /t/ & has /z/ & poops /s/ \\
\hline talked /t/ & doesn't peak & tooth/teeth \\
\hline *sleeped /t/ & doesn't fly & sheep/sheeps \\
\hline didn't watch & nevers open & $\begin{array}{l}\text { peach/peaches } \\
\text { /iz/ }\end{array}$ \\
\hline Spent & knows /z/ & ${ }^{*}$ seas /s/ \\
\hline \multirow[t]{2}{*}{ didn't talk } & means /z/ & pant /s/ \\
\hline & poops /s/ & $\begin{array}{l}\text { beach/ beaches } \\
\text { /iz/ }\end{array}$ \\
\hline
\end{tabular}

The examples provided in table 4 show the interaction the subject had with the tester during the Wug test in a spontaneous conversation. The subject used different words and pronounced all of the morphemes /s/, /z/, /iz/, /t/ correctly. It is important to highlight that the subject pronounced talked /t/ correctly which indicates that she has acquired this morpheme with real verbs.

\section{Conclusion}

There is no doubt that the Wug Test provides many aspects of interlanguage development, particularly the acquisition of morphemes which is the main objective of this study. In this study, the test showed relative frequency of occurrence of the morphemes and use of regular past tense morphemes, plural morphemes of nouns, and third person singular morphemes. This test enabled opportunities to compare the child's pronunciation at two stages of Itzel's growth with the English language: at the age of four and at the age of seven.

It is important to highlight that the OPOL approach and the Minority Language At Home $(\mathrm{ML} @ \mathrm{H})$ have had a treasured effect on Itzel's bilingual first language acquisition. The variables of parent-child communication as well as the consistency, persistency, dedication, and quality and amount of devoted time have been the main issues that have led Itzel to become bilingual.

Indeed, Itzel's development of the morphemes analyzed proved that she has internalized a working system of those morphemes in English, and was able to generalize 
such rules to new cases unconsciously from age four to age seven. In other words, regardless of the word (noun or verb), nonsense or not, the rule was applied.

In Itzel's case, the comparative study at the age of four and at the age of seven demonstrated that her level of acquisition of these morphemes is at its highest peak. However, this study cannot provide an example of every construction or production of the language the child knows. Further studies should be developed to identify Itzel's bilingual first language acquisition.

\section{References}

Armbruster, Bonnie, Lehr, Fran and Osborn, Jean. (2003a). A child becomes a reader: birth through preschool. Washington, D.C.: National Institute for Literacy.

Armbruster, Bonnie, Lehr, Fran and Osborn, Jean. (2003b). Put reading first: The research building blocks for teaching children to read. Washington, D.C.: National Institute for Literacy.

Avery, Peter and Ehrlich, Susan (Eds.). (1992) Teaching American English Pronunciation. Oxford: Oxford University Press.

Baker, Colin. (2011). Foundations of bilingual education and bilingualism ( $5^{\text {th }}$ edition). Clevedon, UK: Multilingual Matters Limited.

Barron-Hauwaert, Suzanne. (2004). Language strategies for bilingual families: The oneparent-one-language approach. Clevedon: Multilingual Matters.

Barron-Hauwaert, Suzanne. (2010). Bilingual siblings: Language use in families. United Kingdom: Channel View Publications.

Berko, Jean. (1958). The child's learning of English morphology. Word, 14, 150-177.

Bowen, Tim and Marks, Jonathan. (1992). The Pronunciation Book: Student-Centered Activities for Pronunciation Work. London: Longman.

Brown, Roger. (1973). A First language: The early stages. Cambridge, MA, United States: Harvard University Press.

Cumpler, Beth. (n.d.). Struggling with the past tense: Verbal acquisition of -ed forms of verbs. Retrieved from http://www.multibriefs.com/briefs/exclusive/struggling with the past tense 1.html\#.VYf yW0aQfEY

Dunst, Carl, Trivette, Carol, Masiello, Tracy, Roper, Nicole and Robyak, Anya. (2006). Framework for developing evidence-Based early literacy learning practices. CELLpapers: Center for Early Literacy Learning, 1(1), 1-12. Retrieved from http://www.earlyliteracylearning.org/cellpapers/cellpapers v1 n1.pdf 
Ferreiro, Emilia \& Teberosky, Ana. (1998). Sistemas de escritura en el desarrollo del niño. United States: Siglo XXI Ediciones.

Fitts, B. P. (2005, october). National early literacy panel: A synthesis of scientific research on young children's early literacy development. Presentation made at the Ohio Department of Education Early Childhood Conference, Columbus, $\mathrm{OH}$.

Golato, Peter. (2005). Processing French: A Psycholinguistic Perspective. New Haven, CT, United States: Yale University Press.

Lonigan, Christopher. (2006). Development, assessment, and promotion of pre literacy skills. Early Education and Development, 17(1), 91-114.

Mitchell, Rosamond, Myles, Florence and Marsden, Emma. (2013). Second language learning theories. England: Routledge.

Murphy, Robert. (2011). The Wug test and major developments since then: The Jean Berko Gleason interview. ETJ Journal, 9(1), 1-5. Retrieved from http://fabefl.com/onlinelearning/resources/Murphy-GLEASONinterview.pdf

Parlakian, Rebecca. (2003). Before the ABCs: Promoting school readiness in infants and toddlers. Washington, DC: Zero to Three.

Pearson, Barbara Zurer \& Language, Living. (2008). Raising a bilingual child: A step-by-step guide for parents. New York: Living Language, U.S.

Quesada, Allen. (2001). Issues on raising a bilingual child in Costa Rica: A myth or a reality. Revista Actualidades Investigativas en Educación, 11(2), 1-21.

Rosenbaum, Nancy. (2014a). Sunday morning exercise: Take the wug test. Retrieved from http://www.onbeing.org/blog/sunday-morning-exercise-take-wug-test/2510

Rosenbaum, Nancy. (2014b). Snug as a wug in a rug. Retrieved from http://www.onbeing.org/blog/snug-wug-rug/3813

Shanaham, Timothy, \& Shanaham, Cinthya. (2008). Teaching disciplinary literacy to adolescents: Rethinking content- area literacy. Harvard Educational Review, 78(1), 4059. doi:10.17763/haer.78.1.v62444321p602101

Van Kleeck, Anne. (1998). Pre Literacy domains and stages: Laying the foundations for beginning reading. Journal of Children's Communication Development, 20(1), 33-51.

Wang, Xiao-lei (2008). Growing up with three languages: Birth to eleven. UK: MPG Books Ltd.

Whitehurst, Graver J., \& Longian, Christopher J. (2001). Emergent literacy: Development from prereaders toreaders. In Susan B. Neuman and David K. Dickinson (Eds.), Handbook of Early Literacy Research (pp. 11-29). New York: Guildford.

Yin, Robert K. (2011). Applications of case study research (3rd ed.). Thousand Oaks, CA: SAGE Publications. 